\section{D.J. Louw}

Prof. D.J. Louw, Professor Emeritus, Research Fellow, Department of Practical and Missional Theology, University of the Free State.

E-mail: djl@sun.ac.za ORCID: http://orcid. org/0000-0003-45120180

\section{DOI: http://dx.doi. org/10.18820/23099089/ actat.v39i2.6 \\ ISSN 1015-8758 (Print) ISSN 2309-9089 (Online) Acta Theologica 2019 39(2):90-113}

Date Published:

13 December 2019

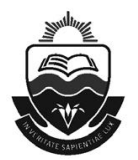

Published by the UFS http://journals.ufs.ac.za/index.php/at (c) Creative Commons With Attribution (CC-BY) OPEN ACCESS

\section{PRACTICAL THEOLOGY}

\section{AS A SNIPPET DISCI- PLINE OF "VERBING AND DISPLAYING THE PRAXIS OF GOD"}

\section{ABSTRACT}

This article aims to develop a diagrammatic depiction of how the different sections or ecclesial snippets ${ }^{1}$ (operational functions) could be portrayed in an integral approach to theory formation in practical theological thinking. It explores the notion of the "praxis of God" as a kind of cohesive factor in a practical teleology, framed by the Christian spiritual paradigm of the passio Dei. It is proposed that an "operative ecclesiology" should contribute to a kind of "spiritual humanism", focusing on what one can call the "beautification" of life; practical theology as fides quaerens beatitudinem.

\section{INTRODUCTION}

In a recent publication, the practical theologian Wilhelm Gräb (2018:2-3) points out the danger of the marginalisation of practical theology. He thus pleads for a practical cultural theology

1 The concept of "snippet" refers to many layers of meaning, namely piece, bit, scrap, fragment, partial perspective, fritting function, or snippet. In combination with different ecclesiologies and the character of practical theology, it indicates that there are many different sides and perspectives. It cannot be captured by one definition or description or approach. 
and the need for a paradigm shift away from doctrine to the challenge of the signification of religious experiences in life. This implies a cultural praxis hermeneutics, in the line of what Jaspers (1932) called chiffreanalyses: ${ }^{2}$ The significance of signs, inherent in matter and present as a kind of cosmic language (Sprache). The implication is that praxis thinking as a cultural endeavour is involved in a hermeneutics of interpretation. Signs as "chiffre" have to be deciphered; they opt as a kind of poetic speech and are connected to the meaning dimension inherent to human actions. They express the creativity of imagination and intentionality of human engagements in life (Jaspers 1962:157).

In fact, practical theology is a unique discipline and cannot be separated from its spiritual dimension. It should, therefore, oscillate between "signals of transcendence" (Berger 1992:121) ${ }^{3}$ and life experiences trying to decipher life, making the unseen realm of religious symbols visual and proclaiming words ${ }^{4}$ (epangelia) as meaningful vehicles, in order to promote the quality of human life and the healing of human beings. In this oscillating event, it is inevitable that practical theology becomes a snippet discipline, scattered between bits and pieces of biblical thinking, doctrinal issues, denominational interests, ministerial challenges and religious experiences. It skippers between clerical interests, experiential reflection, phenomenological approaches, and the pressure of the human sciences for empirically tested data.

\section{PROBLEM IDENTIFICATION}

It is hypothesised that theory formation in practical theology implies more than merely research on ministerial skills, ecclesial practicalities, phenomenological analyses of empirical data regarding religious or faith experiences or activities of social transformation within the publics of civil societal dynamics. With reference to Practical Theology as an academic discipline in theological education, one of the core questions

2 Chiffre is iconic in the sense that it is an aesthetic sign that makes transcendence visual (schaubar). It also signifies "life" (deutbar) and gives meaning to phenomenological awareness and observation (Jaspers 1932:146-148).

3 We each have a desire, or need, for something greater than ourselves; some bigger purpose or meaning in life. In openness to the signals of transcendence the true proportions of our experience are rediscovered. This is the comic relief of redemption; it makes it possible for us to laugh and to play with a new fullness. (Berger 1992:121).

4 Gräb (2018:4) concurs that "Gott" is a human word for the inexplicable and incomprehensible meaning of the whole of being, cosmos and life ("'Gott' ist das menschliche Wort für den unbegreiflichen Sinn des Ganzen"). 
in epistemology is to identify the theological character of the discipline (Louw 2017). What is theological in praxis thinking? If practical theology is not primarily about the application of exegetical material produced by Old and New Testament or by systematic theology (doctrinal dimension), what then is its disciplinary character within an intra-disciplinary setting? If practical theology is not merely about theories borrowed from the human sciences by means of empirical analyses and observational methodologies, what then is the realm of research within a team approach to an interdisciplinary discourse on a social and contextual informed epistemic truth?

Due to a kaleidoscope of models and perspectives on the "what" of practical theology, the article attempts to link the different "theory snippets" in practical theological thinking, in order to promote a holistic approach. In this regard, the article explores whether the notion of "praxis of God" could be theologically explored in terms of the theopaschictic paradigm of the passio Dei. At the same time, the question arises as to whether a practical theological praxis can be separated from its ecclesial roots. If not, how could different ecclesial and pastoral verbs help create an operational approach to a comprehensive understanding of the praxis of God that is designed to promote the spiritual character of practical theological engagements within different social and civil societal contexts.

My presupposition is that specific ecclesial verbing activities are operational exemplifications of the praxis of God (the missio and passio Dei of the epangelia). Together, they weave a tapestry of ecclesial functions that represent the qahal Jahwê - the operational structure of the body of Christ (the fellowship of believers, koinonia, and diaconic outreach to suffering human beings, irrespective of race, gender, sexuality, and religion).

\section{3. "PRAXIS" WITHIN PRACTICAL THEOLOGICAL REFLECTION: THE DANGER OF "EPISTEMIC ARROGANCE"}

To limit praxis to merely practice, functionality and factuality, is, according to Taleb (2010), a kind of positivistic arrogance (Louw 2018c). He calls the limitation of praxis to merely empirically informed data, "epistemic arrogance" - the hubris concerning the limits of our knowledge (Taleb 2010:136). In general, human beings tend to overestimate what they know and underestimate uncertainty, by compressing the range of 
possible uncertain states (that is, by reducing the space of the unknown) (Taleb 2010:140). Knowledge, even if it is functional and operational, refers to networking ideas that represent significance. It is, therefore, a "scientific mistake" to link validity to rational causality with its basis in the evidence of "because of", without taking into consideration the factor of randomness and the highly improbable; that is, the realm of spiritual significance.

According to Aristotle, praxis refers to the fact that an action is instigated by the form or idea that represents both meaningful conceptualisations, as well as identity and function. The idea of an object (thing) (for example, horse-hood) represents a general essence and is embodied in, and by the perceived object (a concrete horse). The form represents the idea and constitutes the "ideal framework, so to speak, into which the thing is moulded. Form also includes function" (Stace 1960:277).

Praxis is, therefore, an expression of form, in order to connect both essence and design with function within concrete moments of observation and behavioural decision-making. In this sense, praxis is not pragmatism and activism, but true discernment and meaning-making. Praxis captures the essence and intention of an act; it represents the idea within all functions and pragmatic expressions.

Praxis thinking is not, in the first place, about practical actions, but it is concerned with the idea that drives the process, and the intention that determines the outcome of the action or intervention. Ideas/belief systems drive, draw, and thus determine the quality of the dynamics.

The oak is in the acorn, ideally, otherwise the oak could never come out of it. Motion is produced not by a mechanical propulsive force, pushing from behind, so to speak, but by an ideal attractive force, drawing the thing (teleology) (Stace 1960:280). 


\section{PRAXIS AS THE FUNCTIONALITY OF VERBS ("OPERATIONAL ECCLESIOLOGY")5: THE "TO-BE" OF SNIPPET ECCLESIAL ENGAGEMENTS AND TELEOLOGICAL MODES OF BEING THE CHURCH ${ }^{6}$}

The term "operative ecclesiology" (Yves Congar) is used to interpret formal ecclesiology to be less an official and institutional category and more an operational category, describing the different modes of being the church as the body of Christ in different societal and cultural contexts. Operative then refers to praxeology, namely how the praxis of God is enfleshed in local and communal contexts on grassroots level, in order to instigate change and transformation. It describes a praxeology of change, unifying fellowship, diaconic outreach and spiritual well-being within social contexts of ethnic divisions and cultural diversity (Berggren 2015).

Praxis in praxeology is a verbal entity. In practice, human actions verbalise belief systems within the existential reality of being functions. The praxis dimension of practical theology can, thus, be related theologically and contextually to the following verbs representing various possible practical theological verbing snippets derived from a hermeneutical approach to networking thinking, strategic communication and relational encounters within the daily dynamics of life:

- Understanding/interpreting (hermeneutics of life);

5 Praxis is not merely practice. Praxis refers to the intentional dimensions of human actions. Praxis is, in this sense, teleological. Praxis is the carrier and vehicle of ideas, wisdom, intentions, commitments, belief systems, philosophies of life enacted within concrete contexts and systems of networking relationships. With this explanation in mind, operational ecclesiology is an attempt to detect the meaning dimension and propositional framework of ecclesial and caregiving functions performed within the realm of the Christian ministry. Operational ecclesiology, thus, describes practical theology as a ministerial and ecclesial enterprise in distinction of sociology, psychology and other disciplines in the humanities. It even supersedes the boundaries of the so-called religious studies, in the sense that it is not primarily interested in religion as a cultural and social phenomenon. It deals with religion as a theological entity, referring to a specific understanding of God as represented in institutional formulas (confessions); visible structures that are called ecclesial structures designed for the spreading of the gospel and the edification of believers, in order to reach out to the need of suffering human beings. An operative ecclesiology wants to contribute to the spiritual well-being and healing of human beings by means of helping relationships and therapeutic engagements.

6 For the following outline, I am making use of concepts already developed in Louw (2008) and systematised in Louw (2016). 
- Communicating/verbalising/conversing, proclaiming;

- Acting, changing, transforming;

- Hoping, anticipating, expecting;

- Imagining, projecting;

- Seeing, envisioning;

- Beautifying;

- Living, meaning-giving, enjoying.

In these snippets of "practical verbs", practical theology poses the question about the reason or intention of human actions as well as the norms and values that direct actions and influence decisions. In his research about the character of practical theology, Browning (1991:9-10) linked praxis thinking to practical reasoning; that is, practical reasoning as the component of intentionality and wisdom thinking.

The practical theologian Friedrich Schleiermacher challenged practical theological thinking to move abstract theory to the "technique" of ministerial doing and acting. He shifted the paradigms of practical theology from the hierarchical and clerical paradigm to the empirical dimension of human experience and religious experiences; to a kind of "experiential piety lived religion" (Louw 2018b:54-65). Practical theology deals with "applied" Christianity and is, in this sense, "technical"; that is, the development of skills and strategies for ministry (which Schleiermacher calls an art).

The turn in praxis-thinking was to link theory to the reality of life events. This is the reason why Burkhart (1983:56) argues that practical theology is about the art of life formation. This was, in fact, the contribution of Schleiermacher: to overcome the distance between human life and what it is meant to be. In terms of recent developments, practical theology is viewed as an action science (Handlungswissenchaft), trying to connect the Christian faith to the praxis and context of our modern or postmodern society (Heitink 1993:18). The implication was that the human sciences became close alleys to theory formation in practical theological reflection (Heitink 1977). Communication and the empirical dimension of human actions, specifically human experiences related to faith, have become an important paradigm for practical theological reflection (Van der Ven 1990:139). ${ }^{7}$ De Gruchy (2001:3-

7 Ganzevoort (2002:39) views the human praxis of faith as the first order of reflection: It is the experiences and constructions of individuals and communities, responding to what they perceive, construct as coming from God, and their discourse about God and towards God. 
4) adds the dimensions of transformation and aesthetic in human actions; that is, our ability to transcend the visible through imagination. Browning (1991:105) calls this act of transcending the vision and normative dimension of practical moral thinking.

According to Van der Ven (2002:23), it is a false dilemma to juxtapose an empirical approach and a normative approach and to separate them in theory formation. Without any doubt, the empirical dimension of practical theology includes a normative dimension. In Habermas' terms ${ }^{8}$ (Van der Ven 2002:21), three normative questions should be posed in practical theology (Louw 2016:100-112).

- The first is the teleological question relating to our personal and communitarian life. Who are we? What do we consider good? What do we strive for? What do we value?

- The second is a deontological question relating to our responsibility to each and everybody and to humankind as a whole. What is just? What is right? What are our obligations?

- The third question is pragmatic or utilistic, relating to effectiveness and efficiency. Which action will produce the intended result?

The purpose of practical theology has become the normative, hermeneutical and communicative praxis of faith. Immink (2003:19) calls this the religious praxis from the perspective of faith: a praxis of faith that includes the praxis of the church (ministry). Van der Ven refers to a functional and contextual ecclesiology which one can call a practical, theological ecclesiology. ${ }^{9}$

The paradigm shift was from the emphasis on proclamation, word, preaching and ecclesial office to human encounter, contextual engagement, liberation, transformation and communication. The theological dimension at stake in this hermeneutical and communicative praxis of faith is the question about the mode (the how) of the encounter, interaction and communication between God and human beings in terms of the different functions of our qualitative intentions in the actions of faithful believers. Human beings should become free so that praxis becomes closely related to the promotion of human rights and dignity (Weiss 2002:17-37). The latter

8 On the implication of Habermas' perspectives on practical theology and theory formation, see De Roest (1998). On the normative perspectives of practical theology, see De Roest (1998:269-353).

9 On the praxis of the church, see Van der Ven (1993:12-13). See also Van der Ven (1990; 2004). 
becomes the praxis field for the demonstration of what can be called the "praxis of God" within human and cultural contexts.

\section{5. "THE COMPASSIONATE PRAXIS OF GOD” - EVENT OF WORDING, VERBING, BEAUTIFYING AND TRANSFORMING (INHABITATIONAL THEOLOGY)}

In his dissertation on the moment of agogy, Firet (1986) refers to the agogic moment of change, edification and transformation that introduced the notion of the "praxis of God" as fundamental for the understanding of the operative impact of God's presence in life (Louw 2008):

At the heart of pastoral role-fulfilment is not the activity of a human being, but the action of God who, by way of the official ministry as intermediary, comes to people in his word (Firet 1986:15).

Without any doubt, pastoral care is closely related to healing and helping functions. According to Heitink's bipolar model, faith and life, proclamation and helping, revelation and experience demarcate a praxis field of divine and human interaction. Thus, the reason why Heitink (1977:15), in his attempt to formulate a theological theory for pastoral caregiving, defines pastoral care (pastoraat) as a mode of rendering help to people in need within the dynamics of an encounter between God and the predicament of our being human. Helping relationships are exercised within the broader context of life, community and the ecclesial praxis of ministry. Pastoral care as a helping profession is then the attempt to establish a helping relationship with people, in order to find a way to deal with questions regarding both faith and life issues. This should be done by means of the light of the gospel and in close connection with communities of faith; that is, the congregation as the body of Christ (Heitink 1977:75).

The close connection between praxis and the pastoral encounters of caregiving points to a very poignant understanding of praxis and its connection to divine engagements, namely the notion of comfort and compassion. One can, thus, argue that paraklesis should be viewed as a core expression of the mode of God within the realm of human existence and its exposure to frailty, weakness, and suffering. Praxis displays a concept of paracletic encounter in pastoral caregiving; it is shaped by the presence of God in life and directed by the theological notion of the passio Dei. Compassion should, therefore, shape the quality of all human encounters. In fact, compassion is about the soulfulness of Christian actions of faithful engagements and as a praxis attempt to deal with questions regarding 
hope, meaning and the purposefulness in life. As an expression of the praxis of God, praxis in practical theology is, therefore, directly related to the response of compassionate being-with and the soulful habitus of care and comfort. Divine presence and human disposition constitute a spiritual praxis of meaningful living (taxonomy of virtues and virtue ethics, Sperry 2002:78-91).

The implication of the previous argumentation is that practical theology should be viewed as a theological discipline (science) and not, in the first place, as a phenomenological science based on merely empirical reflection. Fundamental in theory formation for an academic approach to both pastoral theology and practical theology is the notion (idea) of the "praxis of God" (Louw 2016:95-112). It will further be argued that the "praxis of God" connects pastoral theology and practical theology. Both emanate from wisdom thinking (phronesis) and operate according to the basic assumption that faith and life intersect within the praxis of God. Faith care should be life care. ${ }^{10}$

In terms of Moltmann's theology of hope (Louw 2016:318-348), theopaschitic thinking is a kind of theological praxis thinking, because it refers to the intention of God's divine interventions (the passio Dei) within the trajectories of existential life events. Moltmann (1966:27-28) connects the concept of hope to praxis thinking by emphasising the interplay between hope and reason (Hoffen und Denken). With reference to Zimmerli, Moltmann (1966:102) calls history a "tool" or "instrument" (Werkzeug) of the praxis knowledge of God's revelation. Praxis is connected to the fact that God's praxis is about his promises. It is, therefore, according to Moltmann (1966:130), through the Jewish tradition of wisdom, that epangelia became an indication of the continuity of the actions of God in our history of misery and suffering. Then we need to understand that the hope that emanates from epangelia is not an affect of the heart (Affekt des Herzens), but an indication of a very new mode of reasoning and doing, because hope is about an operative, industrious and active mode of practical reasoning. ${ }^{11}$

A praxis of hope is fundamentally determined and shaped by the notion, conceptual construction, and idea of epangelia. One can say that

10 Glaubenshilfe als Lebenshilfe (Tacke 1975); cura animarum as cura vitae (Louw 2008).

11 Solange die Hoffnung nicht das Denken und Handeln von Menschen umgestaltend ergreift, bleibt sie auf den Kopf stehen und unwirksam. Darum muss die christliche Eschatologie den Versuch machen, Hoffnung ins Weltliche Denken und Denken in die Hoffnung des Glaubens zu bringen (Moltmann 19665:28). 
epangelia describes a transcendental realm of theological ideas that shape the spiritual features of praxis in practical theology.

The "idea" of epangelia also shapes the intentionality in pastoral caregiving (Louw 2016:98). Epangelia refers to the general notion (idea and form) of comfort (the compassion and mercy of God) and shepherding within the tradition of cura animarum (healing from the perspective of cross, salvation, and the dynamics of the Word of God). In this regard, wisdom thinking as expression of the spiritual praxis of God (Schipani 2003) and the belief system of the Christian tradition (faith, grace, hope, and love) play a fundamental role in shaping processes of hoping. Epangelia is an intrinsic component of the Christian belief system.

According to Handzo (2012:24), pastoral care stems from the Christian tradition and developed within the socially contracted context of a religious or faith community, wherein the pastor or faith leader is the community's designated leader who oversees the faith and welfare of the community wherein the community submits to, or acknowledges the leader's overseeing. "The faith they share is a mutually received and agreed upon system of beliefs, actions, and values" (Handzo 2012:24).

The previous theological presupposition can be linked to the following practical theological assumptions for a praxis of hope care.

- The praxis of God refers to the sacrificial will of God (divine intentionality) and paracletic interventions as focused on the meaning and destiny of life, framed by wisdom thinking and wisdom reasoning. In the Old Testament, this intentionality is expressed in the Torah; in the New Testament, in the beatitudes and the fruit of the spirit (called charisma).

- The sustainability of the helping praxis of God is dependent on the notion of the faithfulness of God and its connection to the fulfilment of the promises of God. The praxis of God is meant to reveal compassion and instigate a messianic hope with the expectation of grace and salvation.

- The impact on God images is a shift from the notion of the impassibility of God, as described in doctrinal omni-categories, to the verbing of God, as exhibited in the cry of forsakenness: My God, my God, why hast thou forsaken me; forsakenness as the most primary threat of life and indication of the urgent spiritual need for sustainable hope. "God" as verb (hja as verb in Jehovah), as a praxis of being-there and of becoming, is captured by Mann in his book Joseph and his brothers (1970:31): A God whose nature is future oriented, who was Himself only in process of becoming, and thus was a God of unrest, a God of cares, who must be sought for, for whom one must at all times keep oneself 
free, mobile and in readiness. As Jüngel (1967) aptly formulated: God's being is in becoming (Gottes Sein ist im Werden).

- The common practical area in a theological praxis of helping is the reality of suffering (our human misery and hopelessness) within the human quest for meaning and dignity.

Theology comes from the passion of God, from the open wound of God in one's own life, from Job's indictment of God and the accusing cry of the crucified Christ to God, from the absence of God, and experiences of "the suffering of this present time", whether Auschwitz, Stalingrad, Vietnam, Bosnia or Chernobyl, without end (Moltmann 2002:94).

- The common theological indicator for practical theological thinking is, to my mind, the notion of the compassion of God (the suffering of God and the vista of the healing of life). The comfort in pastoral caregiving emanates from this common theological indicator.

- In practical theology, the following question is at stake: What is meant by soulfulness in the tradition of wisdom, and how does one translate Aristotle's notion of a moral disposition into Christian spiritual language and hope terminology? Thus, the assumption that "soul" is a qualitative and relational category.

The fact is that prudence is embedded in a wisdom tradition marked by covenantal terminology and messianic expectations regarding the engagement of God with his covenantal people. The language of the law (Torah thinking) and the tradition of the Exodus determine practical reason in the Old Testament. Practical reason reckons fundamentally with the promises of God regarding the future of Israel. One can say that the promises of God are, in fact, the "idea" behind all forms of praxis in the Old Testament. Covenantal faith is about a praxis of hope.

\section{PRAXIS AS THE BEAUTIFICATION OF GOD BY MEANS OF MINISTERIAL ENDEAVOURS (TOWARDS A PRACTICAL THEOLOGICAL ECCLESIOLOGY AND PNEUMATOLOGY OF INHABITATION)}

The notion of "aesthetics" in practical theology is not new. In his book Dass Gott schön werde. Praktische Theologie als theologische Ästhetik (1975:93), the practical theologian Rudolph Bohren connects 
a theory of God becoming practical (Praktisch-Werden Gottes) with a theory of God becoming beautiful (Schön-Werden Gottes) by means of pneumatology. Grözinger (1987:132-134) describes aesthetic experience as the practical theological endeavour that seeks those corresponding experiences (Entsprechung) between the content and form of the Christian faith. Aesthetics describes a dialectic movement between presentation and withdrawal/concealment (Grözinger 1987:132), between the form of the revelation and the Being of God.

Aesthetic reasoning prevents faith from experiencing God as an object to be analysed. The latter happened in the positivistic claim of dogmatics trying to describe the attributes of God as entities disengaged from his salvific actions in history and creation (Louw 2001). While the theoretic reason is one of "positing" the other as an "object", the aesthetic reason establishes a relation as one of identification, made possible by the appeal of the I of the dramatis persona or the scene of the artwork (Scharlemann 1991:123). In aesthetic reason, one moves from the "mindfulness" of oneself and of God to the "forgetfulness" of oneself and of God. Between God and human beings is then established not the analytical relationship of objectification, which is often exposed to mere speculation, but the personal relationship of identification, which is open to creativity and imagination, ${ }^{12}$ to awe and surprise. Instead of positing (placing God out there, over against myself) and objectifying (theorising about God as a possible object), aesthetic reason is about appealing and existential operationalisation (self-identification with the appeal of God, due to God's identification with our human misery).

Cilliers (2012:58-64) advocates for aesthetical theology as generation of meaning and hope; even for aesthetical theology as locus theologicus. For Cilliers (2012:60), the praxis of God's presence among us, revealed in certain embodied encounters, should be established as beauty: "When the beauty of God is deciphered through creative imagination, meaning is indicated and constructed" (Cilliers 2012: 64). In this regard

Aesthetics helps us to indicate and create, i.e. to decipher, meaning within the contexts of our essential reality, to make sense out of reality (Cilliers 2012:65).

12 According to Ricoeur (1995:166), imagination comes into play in the transition from semiotic interpretation to existential interpretation. He describes imagination as rule-governed invention and the power of re-description (Ricoeur 1995:144). The narrative texts in the Bible are, for Ricoeur, good examples of creativity in a heuristic model and of the conjunction between fiction and re-description. 
With "beautification of God" in ministerial endeavours, is meant ministerial functions that intend to help human beings discover human dignity, despite hardships, adversities, trials, and suffering. Beauty then refers to frameworks of meaning, the discovery of humane significance and a sustainable source of hope when there is no reasonable reason to hope and to carry on with life.

With reference to a biblical interpretation of "operational", ecclesial functionality can be reduced to the following eight aesthetic dimensions/ modes of ministerial and pastoral beautification: kerygma, didache, paraclesis, koinonia, oikodomein, marturia, leitourgia, and diakonia. Many others could also be identified. However, these eight could be rendered as the most basic modes of ecclesial operations within different diverse contexts; modes that represent the indwelling presence of God through the Spirit in daily life events; that is, presencing as a divine indwelling presence of God in life events describing a pneumatology of inhabitation - Christian spiritual snippets ${ }^{13}$ of how the Spirit infiltrates different modes of exhibiting the gospel within practical theological components - they could be called theological snippets for disciplinary thinking in practical theology.

13 I use the concept "snippet" to indicate that the discipline of Practical Theology is complex and dispersed among many disciplinary components. The research field cannot be precisely demarcated and described. Topics and concepts oscillate between many components of the biblical discipline and Systematic Theology. In the case of New Testament and Old Testament theology, the field is more demarcated when the "What?" question is posed. The Old Testament focuses, in the first place, on the Old Testament text and the New Testament on the text of the New Testament. Systematic Theology is engaged in issues concerning the interpretation of God and how faith knowledge is systematised concerning confessional and ecclesial matters. However, Practical Theology needs to perform an intra-disciplinary hermeneutics, in order to keep up with the findings of Old Testament Theology and New Testament Theology, as well as with the theories in ecclesiology and confessional matters in systematic reflection. On the other hand, it is engaged in existential life issues and the empirical dimension of life. It must be inter-disciplinary in its methodology. Thus, the demand for close cooperation with the human sciences. It has to deal with different perspectives. Often the practical theological researcher is torn between different theories. It oscillates in an osmotic mode between all the disciplines and different approaches. The burning question is: How do we maintain the theological character of practical theology within a kind of snipped approach? Thus, the attempt to reflect on the question: What does an integral theological approach in theory formation and methodological choices in practical theological reflection entail? What is meant by 'seeing the bigger picture' in practical theological reflection? 
With "presencing"14 is meant a kind of encounter, wherein past, present and future intersect in such a way that sensing (experience) and present moment (state of being) coincide in such a way that a linear understanding of time makes place for circularity and a spiral interpretation. Presencing is about the "opening of the human mind" (significant reflection) and the "opening of the heart" (wisdom). It implies the paradigm shift from analytical causative thinking to integrative circular thinking. In Old Testament thinking, presencing refers to the notion of fellowship with God - coram Deo.

In an operational ecclesiology that operates with the different snippets of divine presencing (overwhelming and surprising flashes of a faithful awareness and sublime awe), namely God is there present is his compassion and being-with human beings and the happenstances of life, the following snippet modes can be identified, in order to highlight what is meant by the "praxis of God" in practical theology (Louw 2016:105-161):

- The mode of kerygma or preaching; that is, the subject and field of homiletics in practical theology. The praxis of God in terms of a message to be proclaimed.

- The mode of catechetics and didache: Conveying knowledge about the revelation of God in our history of salvation through Scripture and the confessional tradition of the church; the didactic dimension. The praxis of God in terms of knowledge for spiritual education (spiritual maturity) emanating from the tradition of many scriptural narratives.

- The mode of paraclesis: God's care and comfort for people (pastoral care) and the impact of God images on faith behaviour and processes regarding the ensoulment of human life. The praxis of God as compassionate caregiving encounters, demonstrating the being-with of divine interventions.

14 For the use of the concept "presencing", see its meaning within the parameters of the interplay between a pastoral, psychological and spiritual approach in coaching; ... presencing shifts the place of perception to the source of an emerging future whole - to a future possibility that is seeking to emerge (Kempen 2015:140). Presencing is a blended word combining sensing (feeling the future possibility) and presence (the state of being in the present moment) (Kempen 2015:140). "The boundaries between three types of presence collapse: the presence of the past (current field), the presence of the future (the emerging field of the future), and the presence of one's authentic Self. When this copresence, or merging of the three types of presence, begins to resonate, we experience a profound shift, a change of the place from which we operate." (Kempen 2015:140-141). 
- The mode of koinonia or fellowship: Sharing and the interaction of believers; mutual care. The praxis of God as presencing fellowship in worship.

- The mode of oikodomein: Church growth and church development; church ministry. The praxis of God as edification and the upbuilding of believers in their faithful endeavours.

- The mode of marturia or witness: The missional outreach to the world. The praxis of God as a confessional faith and trusting enfleshment of God's unconditional love and amazing grace.

- The mode of leitourgia or praise and worship: The liturgy of the church. The praxis of God as a "streetwise ritual", in order to demonstrate in daily life divine wisdom and trusting decision-making.

- The mode of diakonia: the sacrificial service of the church in the world and within different social and cultural communities (community development). The praxis of God as reaching out to the predicament of human frailty, suffering and weakness.

\section{THEOLOGICAL PRAXIS PRINCIPLES DESCRIBING THE CHARACTER OF PRACTICAL THEOLOGY AS A THEOLOGICAL ENDEAVOUR IN ACADEMIC THEORY FORMATION}

In considering the way in which spiritual healing in pastoral care is related to the field of practical theology, the following theoretical and academic praxis principles (as related to the praxis of understanding/interpretation; communication/verbalising; acting; hoping; imagining, seeing, beautifying) can be identified. They help to describe the disciplinary and theoretical character of practical theology as an academic enterprise, in theological education for the ministry. These praxis principles, in a disciplinary and academic approach, can be translated into practical theology categories for the formulation of a practical theological theory. ${ }^{15}$ They are, in fact,

15 In many articles in my search for different formulations and attempts to capture the meaning of practical theology and to formulate a theory in order to do research in practical theology in differentiation from the theories of human sciences and empirically based methodology, I proposed variations of the classic formulation of theology as faith seeking understanding (fides quaerens intellectum). This has been done to be in step with the Christian tradition, on the one hand, and to toy with new formulations that link theory with praxis, on the other. See, in this regard, Louw (2016:91-183). The presupposition and 
theological and spiritual categories describing the scientific background of practical theology as a scientific discipline (scientia) (Louw 2011):

- Fides quaerens intellectum: Faith seeking rational (comprehensive) categories for the interpretation of the praxis of God. Pastoral caregiving and practical theological reasoning are about that theological and academic professional field within practical theology that tries to describe and identify appropriate categories of understanding the comfort and compassion of God, in order to portray meaningful images of God within the realm of human suffering and pain: Fides quaerens intellectum: Faith seeking rational categories for the interpretation of the praxis of God.

- Fides quaerens verbum: Faith seeking different forms of proclaiming and verbalising (homiletic event) the gospel as praxis of God. Pastoral caregiving and practical theological reasoning represent the counselling procedures and counselling skills that try to communicate and verbalise the meaning dimension and the comfort of the gospel in such a way that people will be consoled: Fides quaerens verbum: Faith seeking different forms of proclaiming and verbalising the gospel as praxis of God.

- Fides quaerens actum: Faith seeking appropriate actions for emancipation, liberation, transformation, and change. Pastoral caregiving and practical theological reasoning are about the enfleshment and embodiment of the engagement of God with life issues in such a way that concrete actions of comfort, change, liberation, and transformation take place as an expression of the vivid and actual presence of God: fides quaerens actum: Faith seeking

basic assertion is that Practical Theology is that field within theology that deals with the praxis of God; that is, the implications of the God-human encounter for life and the human quest for meaning. Practical Theology includes both ethics and aesthetics - the beautification of life (beautitudinem). It is interested in the intention, motivation and telos of human actions within the field of ministry, communities of faith and social contexts. In this regard, it tries to link appropriate understandings of God with the pastoral and hermeneutical endeavour of understanding the salvific actions of God and his presence in life events (intellectum). It is also about the communication and proclamation of the gospel (verbum); the transformation and liberation of social contexts (actum); the fostering of a vivid hope within the realm of suffering (spem); the symbolic and metaphorical expression of the Christian faith through imagination, creativity and ritual (imaginem), and the portrayal of Christian spirituality through visual images, audio sounds and narratives that contain meaning and represent the "seeing of the unseen" within virtual reality (visum). 
appropriate actions for liberation, transformation, and change. Note that the dimension of action immediately emphasises the importance of ethics in pastoral care.

- Fides quaerens spem: Faith seeking to promote hope not as wishful thinking, but as an ontological category: a new state of mons and a new state of being based on the faithfulness of God as exemplified in his fulfilled promises: I will be your God (promisiology).

- Fides quaerens imaginem: Faith seeking symbolic and metaphorical expressions that can heal and beautify the cosmos. Pastoral caregiving and practical theological reasoning inspire people for the ensoulment of life by stimulating creativity and imagination in such a way that human souls can be illuminated and opened up for the aesthetic dimension of life through symbol, metaphor, and liturgical rituals; faith seeking beauty, aesthetic and creative expression of the content of faith: Fides quaerens imaginem: Faith seeking symbolic and metaphorical expressions that can heal and beautify the cosmos. Imagination and creativity represent the dimension of aesthetics in pastoral comfort: the healing that emanates from God's grace and salvation. This consoling dimension can be related directly to the realm of the sublime in spirituality. "Sublime" is the French translation of the Greek peri hupsous, which literally means "about the elevated" (Couvée 2005:83). Fides quaerens visum: Faith seeking alternative options for projecting, dreaming, and fostering a different and more humane society and environment. Pastoral caregiving and practical theological reasoning open people's eyes (viewers) to "see" traces of God's presence (seeing the unseen) in life through the spiritual dimension incorporated within icons, drama, storytelling, narratives, symbols, metaphors, and virtual reality.

- Fides quaerens vivendi: Faith seeking lifestyles that demonstrate the inhabitating presence of the Holy Spirit within the relationships of human beings on all levels of human encounters and institutions. Pastoral care and practical theological reasoning are focused on promoting qualitative structures for humane living and fostering of a safe and clean environment for the fostering of human dignity and justice for all.

- Fides quaerens beautitudinem: Faith seeking meaningful ventures to instil meaning in life and to transform inhumane structures into directors for promoting human dignity and to maintain justice in the public of daily living (the establishment of a spiritual humanism). The philosopher Levinas (1987) pointed out that trustworthiness, loyalty 
and justice are the cornerstones in the encounter with the other ${ }^{16}$ and for the establishment of human freedom and an ethics of responsibility (Levinas 1972). The concept of beauty ${ }^{17}$ in practical theology and pastoral care refers to the dimension of healing and reconstruction of human life; it represents the urge for constructive change and the expression of meaning in life in such a way that instils hope.

\section{FUNCTIONS ${ }^{18}$ OF PASTORAL CARE AND COUNSELLING WITHIN THE PARAMETERS OF AN OPERATIVE ECCLESIOLOGY AND PASTORAL HERMENEUTICS}

The above praxis principles in pastoral care, as a professional and academic field in theological education, as well as within the practical theological mode of comfort, help us gain greater clarity on the functions of pastoral care and counselling (Louw 2016:373-381).

16 Responsibility precedes freedom. It is not a responsibility for oneself (responsibilité pour soi); it is not encapsulated by the existentialistic notion that you are only responsible for yourself. It is about a responsibility to and for the other (responsabilite pour l'autre). This responsibility for the other is not a choice, but an existential givenness. Levinas (1987:23) links his idea of the infinite to responsibility. The idea of the infinite implies in a very poignant sense "the infinite of responsibility"; it is a responsibility for subjectivity as structured by and embedded in the being for the other (être pour l'autre).

17 The concept of beauty is related to the struggle to come to terms with the attempt of humankind to transcend all earthly boundaries and limitations. To be connected to the sublime by means of beauty is part of spiritual healing. Sublime is a quality possessed by a work of art, which, as a result of the intention and inspiration rather than reasoned judgement, does not so much convince the viewer as it thrills or transports him (Couvée 2005:83). Aesthetics can be related to what is called in German "das Erhabene". Rudolf Otto in "Das Heilige" argues that the sublime expresses the numinous as sui generis, irreducible to any other factor, an irrational and non-moral aspect of holiness. The sublime also represents the dimension of light and mystery. Good examples are the Russian words vozvyshennoe (elevated, lofty), vysokoe (high, elevated), velichestvennoe (magnificence, grandeur), vostorg (rapture) and voskhishenie (ecstasy, delight) (Couvée 2005:86).

18 For a more detail exposition of the different functions in pastoral care and counselling, see Lartey (1997:37-41). 
Through the ages, the notion of shepherding has become a classic representation of pastoral care as a theological endeavour (cura animarum, as related to the notion of salvation). Hiltner (1958:55) discusses this idea in his theological theory on pastoral care. Hiltner (1959) argues that all the actions of the caregiver should be understood from the shepherding perspective: solicitous care.

Within the tradition of cura animarum, the following functions have been identified within different models of care and theories on pastoral counselling (see Lartey 1997; Louw 2016): healing, sustaining, guiding, reconciling, nurturing, liberating, empowering, narrating/interpreting, advocating, hospitable reaching out (diakonia), stewarding (cura vitae as cura terrae). Their significance and impact on our being human are to restore human dignity; to create encountering spaces for humane being, due to a sense of belongingness, and to beautify (heal) life within empowering acts of embracement: the praxis spirit (soulfulness) of unconditional love (passio Dei - spiritual humanism).

\section{ON SEEING THE BIGGER PICTURE IN AN OPERATIONAL ECCLESIOLOGY: A DIAGRAMMATIC DESIGN AND DEPICTION}

The previous outline of the basic pastoral functions in an integrative approach towards spiritual wholeness and healing could be depicted in the following diagram that connects anthropology with an ecclesial praxis. It demonstrates the networking dynamics of an operative ecclesiology within the framework of mutual interconnectedness. It is designed to help researchers in practical theology discover the broad and complicated scope of practical theology as a scientific, disciplinary and theological endeavour within the context of academic training and theory formation.

The diagrammatic design is based on the presupposition that caring functions in human encounters can be aligned along the basics of four fundamental features of "counselling people", namely be with them and signify life; listen to them and feel with them; probing the rational and cognitive dimension of thinking and paradigmatic frameworks (ideas, convictions, philosophies of life, belief systems), and acting by means of goal-setting. Four sectors or dimensions in a pastoral anthropology are then mutually at stake: the cognitive, conative, affective and spiritual realms of being human. 


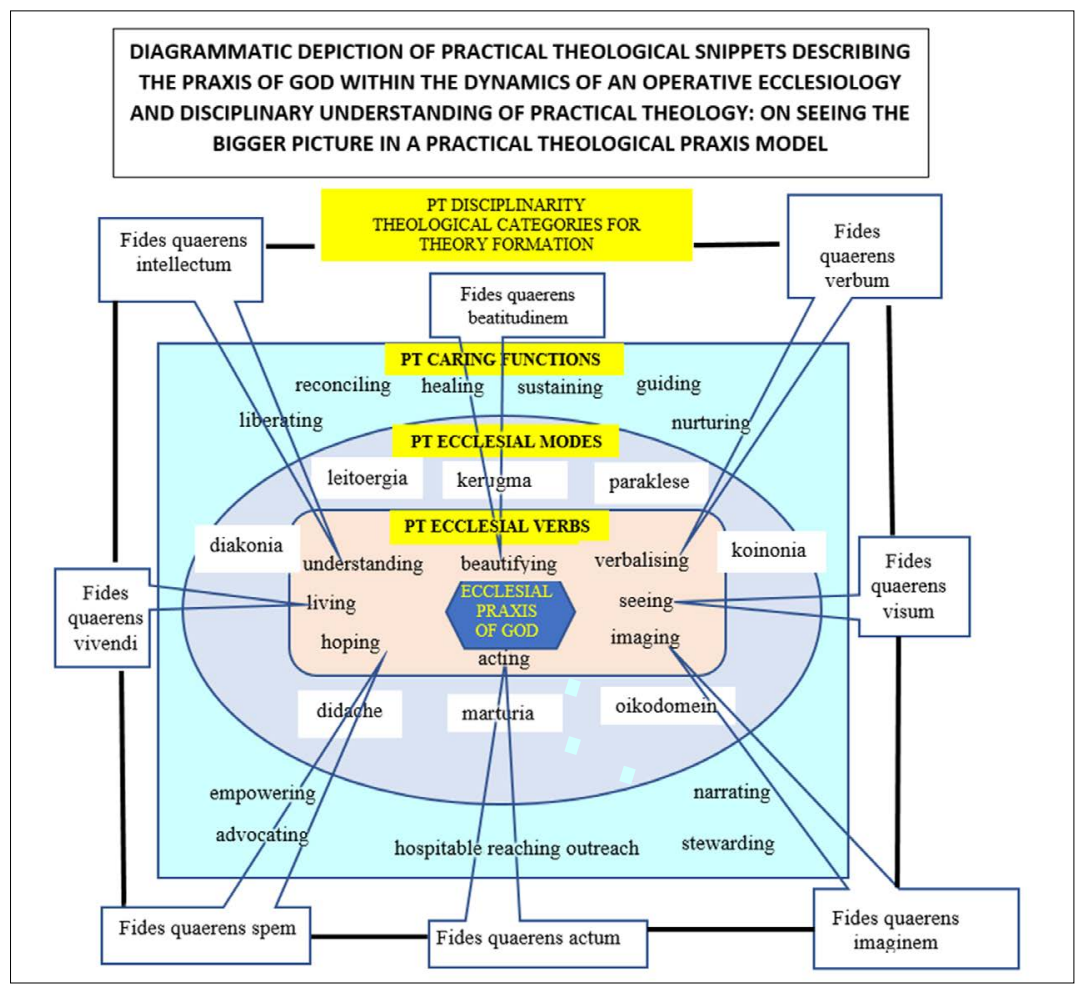

The diagram above is designed to link the different mentioned practical theological flitters together in a more comprehensive and integral approach to theory formation in practical theological thinking. It can be called: on seeing the bigger picture of the broad scope of practical theology as a theological endeavour and scientific discipline in Christian theology. In the centre is the coherent theological and praxis factor of the praxis of God, as described in the modes of divine verbing engagements.

\section{CONCLUSION}

Ecclesial praxeology reflects the basic assumption, as argued throughout the document, namely that practical theology should maintain its theological character in its attempt to link epistemic truth to both the spiritual dimension of the discipline, namely the "praxis of God", and the existential dimension of our being human, namely the quest for meaning within the realm of human suffering, the public of daily living, and the reality of death and dying. 
The undergirding argument was that insight into the structures and functions of an operative ecclesiology (verbing snippets) will help caregivers and ministers to understand their professional identity in distinction of the disciplinary identity of others within a team approach to the profession of helping and healing. An operational ecclesiology reflects the passio Dei by means of a pastoral presencing: Compassionate being-there with them. In this sense, praxis thinking contributes to healing and helping; that is, to the spiritual endeavour of the beautification of life (fides quaerens beatitudinem).

\section{BIBLIOGRAPHY}

BERGER, P.L.

1992. A far glory: The quest for faith in an age of credulity. New York: The Free Press.

\section{Berggren, E.}

2015. Catholicity challenging ethnicity. An ecclesiological study of churches in post-apartheid South Africa. Uppsala: Uppsala University.

BOHREN, R.

1975. Dass Gott schön werde: Praktische Theologie als theologische Ästhetik. München: Kaiser Verlag.

BRowning, D.S.

1991. A fundamental practical theology. Minneapolis, MN: Fortress Press.

BURKHART, J.E.

1983. Schleiermacher's vision for theology. In: D.S. Browning (ed.), Practical theology (San Francisco, CA: Harper and Row), pp. 42-60.

Cilliers, J.

2012. Dancing with deity. Re-imagining the beauty of worship. Wellington: Bible Media.

Couvée, P.

2005. Aspects of sublime and istinnost in contemporary Russian poetry: The mystic sublime in the poetry of Leonid Aronzon and Olga Sedakovs. In: W. van den Bercken \& J. Sutton, Aesthetics as a religious factor in Eastern and Western Christianity (Leuven: Peeters), pp. 81-100.

DE GRUCHY, J.W.

2001. Christianity, art and transformation. Theological aesthetics in the struggle for justice. Cambridge: Cambridge University Press.

De Roest, $\mathrm{H}$.

1998. Communicative identity. Habermas' perspectives of discourse as a support for practical theology. Kampen: Kok. 
ELLENS, J.H.

1987. Psychotheology: Key issues. Pretoria: University of South Africa.

FIRET, J.

1986. Dynamics in pastoring. Grand Rapids, MI: Wm B. Eerdmans.

GANZEVOORT, R.R.

2002.WYSIWYG.Socialconstruction in practicaltheologicalepistemology.Journal of Empirical Theology 15(2):34-42. https://doi.org/10.1163/157092502X00027

GRÄB, W.

2018. Vom Menschsein und der Religion. Praktische Theologie in Geschichte und Gegenwart, 30. Tübingen: MohrSiebeck. https://doi.org/10.1628/978-3-16-156565-6

Grözinger, A. 1987. Praktische Theologie und Ästhetik. München: Kaiser.

HaNDZO, G.

2012. The process of spiritual/pastoral care. A general theory for providing spiritual/ pastoral care using palliative care as a paradigm. In: B. Stephan \& B. Roberts (eds), A practical clergy and chaplain's handbook (Woodstock: Skylight Paths), pp. 21-41.

Heitink, G.

1977. Pastoraat als hulpverlening: Inleiding in de pastorale theologie en psychologie. Kampen: Kok.

1993. Praktische theologie. Kampen: Kok.

HiLtNeR, S.

1958. Preface to pastoral theology. Nashville, TN: Abingdon.

1959. The Christian shepherd. Some aspects of pastoral care. Nashville, TN: Abingdon.

IMMINK, F.G.

2003. In God geloven. Een practisch-theologische reconstructie. Zoetermeer: Meinema.

JASPERS, K.

1932. Philosophie. Dritter Band. Metaphysik. Berlin: Verlag von Julius Spinger. https://doi.org/10.1007/978-3-642-99340-4

1962. Der Philosophische Glaube angesichts der Offenbarung. München: Piper Verlag.

JÜNGEL, E.

1967. Gottes Sein ist im Werden. Tübingen: JCB Mohr (Paul Siebeck).

Kempen, M.

2015. Coaching als abduktiver Prozess vor dem bleibenden Geheimnis. Die Theorie $U$ aus pastoralpsychologischer Perspektive unpublished. Doctoral dissertation. Frankfurt am Main Philosophisch - Theologische Hochschule, Sankt Georgen, Institut fur Pastoralpsychologie und Spiritualität. 


\section{LARTEY, E.Y.}

1997. In living colour. An intercultural approach to pastoral care and counselling. London: Cassell.

Levinas, E.

1972. Humanisme de l'autre homme. Montpellier: Fata Morgana.

1987. De totaliteit en het oneindige. Translated by T. de Boer \& C. Bremmers. Notes by T. de Boer. Baarn: Ambo.

Louw, D.J.

2001. Creative hope and imagination in a practical theology of aesthetic (artistic) reason. $4^{\text {th }}$ International Academy of Practical Theology. Quebec International Conference, Canada, 14-20 May 1999. In: P. Ballard \& P. Couture (eds), Creativity, imagination and criticism: The expressive dimension in practical theology (Cardiff: Cardiff Academic Press), pp. 91-104.

2008. Cura vitae. Illness and the healing of life. Wellington: Lux Verbi.

2011. Ta splanchna: A theopaschitic approach to a hermeneutics of God's praxis. From zombie categories to passion categories in theory formation for a practical theology of the intestines. HTS Teologiese Studies/Theological Studies 67(3), Art.\#1087, 13 pages. http://dx.doi.org/10.4102/hts.v67i3.1087

2016. Wholeness in hope care. On nurturing the beauty of the human soul in spiritual healing. Wien: Lit Verlag.

2017. Practical theology as life science: Fides quaerens vivendi and its connection to Hebrew thinking (Hālak). Die Skriflig/In Luce Verbi 51(1):1-13.

2018(a). Preaching as poetic thinking (Fides quaerens imaginem) within the framework of an aesthetics of life and the beautification of lifestyles. In: J. Cilliers \& L. Hansen (eds), Preaching promise within the paradoxes of life (Stellenbosch: Sun Media, Studia Homiletica 11), pp. 85-102.

2018(b). 'Verbing God' within the dynamics of 'lived religion'. 'Sympathetic rites of passage' in a practical theological approach to the complexity of everyday life. In: L. Charbonnier, J. Cilliers, M. Mader, C. Wepener \& B. Weil (eds), Pluralisation and social change. Dynamics of lived religion in South Africa (Berlin: De Gruyter), pp. 51-66.

2018(c). The "frail researcher". The "threat of empiricism" within the quest for sound methodology in practical theological research. Die Skriflig/ln Luce Verbi 52(1): a2361.

ManN, T.

1970. Joseph and his brothers. London: Secker \& Warburg.

Moltmann, J.

1966. Theologie der Hofnung. München: Kaiser.

2002. A lived theology. In: D.C. Marks (ed.), Shaping a theological mind. Theological context and methodology (Aldershot: Ashgate), pp. 87-96. 


\section{Ricoeur, P.}

1995. Figuring the sacred. Religion, narrative, and imagination. Minneapolis, MN: Fortress Press.

SchaRLEMANN, R.P.

1991. The reason of following. Christology and the ecstatic 1. Chicago, ILL: The University of Chicago Press.

SCHIPANI, D.S.

2003. The way of wisdom in pastoral counseling. Elkhardt: Institute of Menonite Studies.

SPERRY, L.

2002. Transforming self and community. Revisioning pastoral counseling and spiritual direction. Collegeville, MN: The Liturgical Press.

Stace, W.T. 1960. A critical history of Greek philosophy. London: MacMillan.

TACKE, $\mathrm{H}$.

1975. Glaubenshilfe als Lebenshilfe: Probleme und Chancen heutiger Seelsorge. Neukirchen-Vluyn: Neukirchener.

TALEB, N.N.

2010. The black swan. The impact of the highly improbable. London: Penguin Books.

VAN DER Ven, J.A.

1990. Entwurf einer empirischen Theologie. Kampen/Weinheim: J.H. Kok Publishing House/Deutscher Studien Verlag.

1993. Ecclesiologie in context. Kampen: Kok.

2002. Anempiricalornormativeapproachtopractical-theologicalresearch. Journal of Empirical Theology 15(2):5-33. https://doi.org/10.1163/157092502X00018

WeISS, $\mathrm{H}$.

2002. Die Entdeckung Interkultureller Seelsorge. Entwicklung interkultureller Kompotenz in Seelsorge und Beratung durch internationale Begegnung. In: K. Federschmidt et al, Interkulturelle Seelsorge (Neukirchen-Vluyn: Neukirchener Verlag), pp. 17-37.

Keywords

Operative ecclesiology

Functions in pastoral caregiving

Beautification of life

\section{Trefwoorde}

Operasionele ekklesiologie

Funksies in pastorale sorg

Mooimaak van lewe 